LIFE IN THE

AGE OF DRONE WARFARE 
This page intentionally left blank 


\section{LIFE IN THE \\ AGE OF DRONE WARFARE}

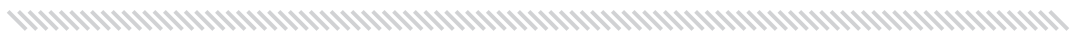

LISA PARKS AND CAREN KAPLAN, Editors

DUKE UNIVERSITY PRESS

DURHAM AND LONDON 
(C) 2017 Duke University Press

All rights reserved

Printed in the United States of America on acid-free paper $\infty$

Text design by Adrianna Sutton

Cover design by Matthew Tauch

Typeset in Sabon and Din by Westchester Publishing Services

Library of Congress Cataloging-in-Publication Data

Names: Parks, Lisa, editor. I Kaplan, Caren, [date-] editor.

Title: Life in the age of drone warfare / Lisa Parks and Caren Kaplan, editors.

Description: Durham : Duke University Press, 2017. I Includes bibliographical references and index. I Description based on print version record and cIP data provided by publisher; resource not viewed. Identifiers: LCCN 20I70I402I (print) I LCCN 20I70I68 I 5 (ebook)

ISBN 97808223728 I 3 (ebook)

ISBN 9780822369585 (hardcover : alk. paper)

ISBN 9780822369738 (pbk. : alk. paper)

Subjects: LCSH: Drone aircraft. I Air warfare. I Drone aircraft pilots.

Classification: LCC UGI 242.D7 (ebook) I LCC UGI242.D7 L54 2017 (print) | DDC $358.4 /$ I $4-\mathrm{dc} 23$

LC record available at https://lccn.loc.gov/20I70I402I

Cover art: Drone Shadow installation by James Bridle (jamesbridle.com), Ljubljana, 20I 5. Photograph courtesy of Aksioma Institute for Contemporary Art. 